\title{
En evolusjonær forståelse av kronisk utmattelsessyndrom
}

\author{
I jakten på årsaker til kronisk utmattelsessyndrom er evolusjonær kausalitet blitt viet lite oppmerksomhet. \\ Tilstandens fenotypiske uttrykk kan ha økt individers forventede genetiske bidrag til fremtidige generasjoner \\ ved å utgjøre en barriere mot kollaps og slik muliggjøre viktig langvarig beskyttelse av reproduktiv suksess.
}

Ved kronisk utmattelsessyndrom ledsages kraftig og vedvarende energisvikt av plager som svekket kognitiv fungering, søvnforstyrrelser, smerter og ømfintlighet for sanseinntrykk (1-4). Fordi årsaken fremdeles er ukjent og fordi denne tilstanden fører med seg så omfattende personlige, familiemessige og samfunnsøkonomiske konsekvenser $(5,6)$ er intensiv forskning av sentral betydning. Men ensidig vektlegging av umiddelbar, nærliggende kausalitet kan føre til at fenomenets eventuelle funksjon for overlevelse og reproduksjon ikke blir belyst.

Når man studerer årsakene til kronisk utmattelsessyndrom, kan man spørre hvordan dette skjer, for eksempel som følge av en autoimmun patologisk mekanisme (7) eller i sammenheng med en virusinfeksjon (8). I tillegg til dette kan man stille spørsmål om evolusjonær kausalitet: Hvorfor får mennesker kronisk utmattelsessyndrom?

I denne artikkelen argumenterer jeg for at kronisk utmattelsessyndrom er en tilstand som kan være adaptiv. Mer spesifikt presenterer jeg først en hypotese om at den fungerer som en barriere mot permanent og omfattende funksjonstap i livssituasjoner der den totale belastningen individet utsettes for er av slikt omfang og slik varighet at risikoen for kollaps og død er vesentlig økt. I forlengelsen av denne hypotesen argumenterer jeg for at kronisk utmattelsessyndrom kan være en tilpasning og utleder hovedkonsekvensen av dette for forståelsen denne tilstanden.

\section{En adaptiv barriere mot kollaps}

I intervjurekker med klienter med kronisk utmattelsessyndrom har jeg fått grunn til å tenke på denne tilstanden av energisvikt og tilhørende plager som en adaptiv kvalitet $i$ et menneskeliv. Bakgrunnen for denne paradoksale hypotesen er at klientene, i tillegg til å fremstå med tilstandens karakteristisk symptomer, også har samvariert på følgende måte: I tiden frem mot da energisvikten inntraff, tok ingen av dem skritt i retning av å redusere det de selv beskriver som et ikke-bærekraftig forbruk av egne energiressurser i totalsituasjoner preget av alvorlig belastning på flere områder. Tvert imot er dette forbruket blitt opprettholdt uendret frem til et punkt der den energisvikten som er hovedkjennetegnet på kro- nisk utmattelsessyndrom har gjort seg gjeldende. Klientene forteller meg videre at de på tidspunktet da energisvikten inntraff, ikke hadde noen planer om kursendring.

På kort tid har de gått fra svært belastende livssituasjoner direkte over til å være ute av stand til å opprettholde de fleste av sine sosiale og profesjonelle forpliktelser. De er blitt tvunget til å redusere sin innsats $i$ familielivet til et minimum og tilbringe mye av sin tid hvilende. Til tross for omfanget av dette dramatiske funksjonsfallet har jeg funnet det vanskelig ikke å tenke på hva som ville ha skjedd dersom de hadde fått fortsette. I intervjuer med klientene begynte jeg etter hvert å stille følgende spørsmål: Hva hadde skjedd dersom disse menneskene ikke-diametralt mot egen vilje - var blitt stoppet?

\section{«l en pågående situa- sjon der et individ risikerer total kollaps vil kronisk tretthets- syndrom på denne måten kunne være en adaptiv barriere»}

Kronisk utmattelsessyndrom er adaptivt, dvs. det øker egnetheten (på engelsk: fitness) dersom den tvungne omlegging av livsførselen det medfører forhindrer at individet fortsetter en ikke-bærekraftig rovdrift på egne energiressurser og slik avverger en mye mer alvorlig og potensielt fatal kollaps. Selv langvarig energisvikt er adaptivt dersom det avverger kollaps og sikrer overlevelse.

I evolusjonen er det å lykkes med reproduksjon det som betyr noe. Én ting er å tenke at det kan være hensiktsmessig å bli stoppet på veien til kollaps, noe annet er å mene at dette skal ha økt individers reproduktive suksess. Paradoksalt nok er det akkurat denne statusen kronisk utmattelsessyndrom kan ha hatt i den menneskelige evolusjonen.

\section{Et vern om langt liv}

Den menneskelige reproduksjonen avviker fra den til mange andre arter ved at suksess ikke først og fremst måles i selve produksjonen av avkom. Mens de fleste andre arter er klare til å leve comme it faut mer eller mindre i det øyeblikket de kommer til verden, er mennesker ikke fullt ut kompetente til å fungere optimalt før etter mesteparten av to tiår med utvikling og læring. For at barn skal lykkes, er de avhengige av at storparten av foreldrenes reproduktive kapasitet, dvs. energiforbruk avsatt til reproduksjon, vies til beskyttelse av deres utvikling. For å si det på en annen måte: For at barn senere skal lykkes på den reproduktive arena, er de avhengig av at foreldrene bruker energi over lang tid på å oppdra og verne dem. Hvis ikke ens barn lykkes reproduktivt, er dette i evolusjonsmessig forstand det samme som aldri å ha fått barn i utgangspunktet - altså en genetisk blindvei.

Ikke bare er menneskelig reproduktiv suksess en funksjon av å legge til rette for egne barns senere reproduksjon - besteforeldre maksimerer sin reproduktive suksess gjennom å legge til rette for både barn og barnebarn. Den amerikanske antropologen Kristen Hawkes har vist at selv om kvinner kunne fått barn etter menopausen, ville de likevel i større grad øke sitt genetiske bidrag til fremtidige generasjoner gjennom godt besteforeldreskap enn gjennom nye svangerskap (9). Dette kan være noe av den paradoksale evolusjonære årsaken til kvinners menopause. Ved å bidra med omsorg og ressurser til barn og barnebarn kan en bestemor øke sannsynligheten for at datteren tidligere kan få flere barn enn om hun måtte ta vare på seg selv og barnet alene (9).

For å maksimere det genetiske bidraget til fremtidige generasjoner må altså mennesker verne om både sine barns og sine barnebarns reproduktive suksess. En sentral forutsetning for dette er et langt liv med tilstrekkelig høyt funksjonsnivå. Manglende kapasitet til å avbryte rovdrift på egne ressurser i belastende totalsituasjoner kan være uforenlig med dette. I en pågående situasjon der et individ risikerer total kollaps vil kronisk tretthetssyndrom på denne måten kunne være en adaptiv barriere. Tilstandens fenotypiske uttrykk kan imidlertid være mer enn adaptivt. Husk at mens et trekk 
er adaptivt når det øker egnetheten, er det en tilpasning bare hvis det foreligger i en aktuell populasjon gjennom arv, fordi trekket økte foregående generasjoners egnethet (10).

I menneskets evolusjon kan det fenotypiske uttrykket til kronisk utmattelsessyndrom ha representert en barriere mot reproduktiv fiasko ved at viktige ressurspersoner unngikk gjennomgripende kollaps og på denne måten kunne ha en omsorgs- og opplæringsrolle for to påfølgende generasjoner. Dersom dette er riktig, vil kronisk utmattelsessyndrom ikke bare være adaptivt, men også en tilpasning.

\section{En evolusjonær forståelse}

Jeg har presentert argumenter i favør av en forståelse av kronisk utmattelsessyndrom som et sikkerhetsnett i belastende livssituasjoner der mennesker ikke klarer å avslutte rovdrift på egne energiressurser. En slik sikring vil kunne ha konsekvenser for bærerens forventede genetiske bidrag til fremtidige generasjoner. Kronisk utmattelsessyndrom som fenotypisk uttrykk kan tenkes å øke et individs egnethet gjennom å stoppe en selvdestruktiv prosess på vei mot kollaps på en effektiv måte og slik legge til rette for beskyttelse av reproduksjonen over et langt liv. Dine barn må lykkes reproduktivt for at ditt genetiske bidrag til fremtidige generasjoner skal sikres, og for å få til dette, er funksjonsdyktige primære omsorgsgivere sentrale i flere tiår.
Dersom dette er en fysiologisk forankret systemsikring mot videreføring av et ikkebærekraftig energiforbruk, har det konsekvenser for hvordan vi forstår oppfølging av personer som har vært i livssituasjoner der kronisk utmattelsessyndrom er utløst. Den viktigste av disse konsekvensene er kanskje at kronisk utmattelsessyndrom forstås som et signal til den berørte om et behov for omlegging av tilnærmingen til bruk av egne energiressurser. I dette perspektivet vil kronisk utmattelsessyndrom være systemets kommunikasjon til den berørte om at vedkommendes livsførsel er mer eller mindre uforenlig med et langt liv. I oppfølgingen av personer med kronisk utmattelsessyndrom kan et slikt perspektiv bidra til å gjøre en personlig krise om til en mulighet for personlig vekst.

\section{Rune Karlson}

rune.karlson@ppt.rogfk.no

Psykologisk-pedagogisk tjeneste

for videregående skoler

Rogaland fylkeskommune

Stavanger

Rune Karlson (f. 1971) er spesialist i klinisk psykologi. Han arbeider ved Pedagogisk-psykologisk tjeneste for videregående skoler i Rogaland og er i tillegg privatpraktiserende psykolog i Stavanger.

Ingen oppgitte interessekonflikter.
Litteratur

1. Afari N Buchwald D. Chronic fatigue syndromea review. Am J Psychiatry 2003; 160: 221-36.

2. Fukada K, Straus SE, Hickie I et al. The chronic fatigue syndrome. A comprehensive approach to its definition and study. Ann Intern Med 2004; 121: 953-9

3. Prins JB, van der Meer JW, Bleijenberg G. Chronic fatigue syndrome. Lancet 2006; 367: 346-55.

4. Wyller VB. The chronic fatigue syndrome. An update. Acta Neurol Scand Suppl 2007; 115 (suppl 187): $7-14$

5. Capelli E, Zola R, Lorusso L et al. Chronic fatigue syndrome/myalgic encephalomyelitis. An update. Int J Immunopathol Pharmacol 2010; 23: 981-9.

6. Devanur LD, Kerr JR. Chronic fatigue syndrome. J Clin Virol 2006; 37: 139-50.

7. Fluge $\emptyset$, Bruland O, Risa K et al. Benefit from Blymphocyte depletion using the anti-CD20 antibody rituximab in chronic fatigue syndrome. A doubleblind and placebo-controlled study. PLoS ONE 2011; 6: e26358.

8. Lombardi VC, Ruscetti FW, Das Gupta J et al. Detection of an infectious retrovirus, XMRV, in blood cells of patients with chronic fatigue syndrome. Science; 326: 585-9.

9. Hawkes K. Grandmothers and the evolution of human longevity. Am J Human Biol 2003; 15: $380-400$

10. Buller DJ. Adapting minds. Evolutionary psychology and the persistent quest for human nature. Cambridge, MA: MIT Press, 2005

Mottatt 8.11. 2011, første revisjon innsendt 31.12. 2011, godkjent 26.1. 2012. Medisinsk redaktør Petter Gjersvik. 